\title{
KILAT
}

Vol. 10, No. 1, April 2021, P-ISSN 2089-1245, E-ISSN 2655-4925

DOI: https://doi.org/10.33322/kilat.v10i1.1037

\section{Analisis Kualitas Daya Listrik Pada Penggunaan Modul Surya Sederhana Untuk Pompa Air Rumah Tangga}

\author{
Syarif Hidayat ; Agung Hariyanto ${ }^{2}$; Tasdik Darmana ${ }^{3}$ \\ ${ }^{1,2,3}$ Institut Teknologi PLN \\ ${ }^{1}$ syarifhidayat@itpln.ac.id
}

\begin{abstract}
The use of solar modules to meet the needs of everyday life is something interesting to use. Harmonics is a phenomenon of power quality deviation that can distort voltage and current waveforms. In this experiment, a simple inverter with $1000 \mathrm{~W}$ capability will be used, then will be loaded with water pumps and other household appliances. The method used is to measure the power factor and harmonics generated by using a measuring device. In this process needs to be assessed and will be seen using the ability of the inverter and the quality of the electric power generated in this solar power generation system. Based on the results of measurements and calculations on a water pump with a power of $680 \mathrm{~W}$ and 1 incandescent lamp with a power of 60 Watts, the value of the power factor generated is 0.95 while the total harmonic voltage distortion (THDv) value is when the water pump load is THDv $1.9 \%$ and at THDv incandescent lamps $1.6 \%$.
\end{abstract}

Keywords: Inverter, household water pump, electric power quality

\begin{abstract}
ABSTRAK
Penggunaan modul surya untuk pemenuhan kebutuhan hidup sehari-hari merupakan sesuatu yang menarik untuk diteliti. Harmonik merupakan salah satu fenomena penyimpangan kualitas daya yang dapat mendistorsi bentuk gelombang tegangan dan arus. Pada percobaan kali akan dipergunakan inverter sederhana dengan kemampuan $1000 \mathrm{~W}$ kemudian diberi beban pompa air dan peralatan rumah tangga lainnya. Metode yang digunakan adalah dengan melakukan pengukuran faktor daya dan harmonisa yang ditimbulkan dengan menggunakan alat pengukur. Pada proses ini perlu pengkajian dan akan dilihat bagaimana kemampuan inverter dan kualitas daya listrik yang dihasilkan pada sistem pembangkit listrik tenaga surya sederhana ini. Berdasarkan hasil pengukuran dan perhitungan pada beban pompa air dengan daya $680 \mathrm{~W}$ dan 1 buah lampu pijar dengan daya 60 Watt, nilai faktor daya yang ditimbulkan sebesar 0,95 sedangkan nilai total harmonik distorsi tegangan (THDv) yaitu pada beban pompa air THDv 1,9\% dan pada beban lampu pijar THDv 1,6\%.
\end{abstract}

Kata kunci: Inverter, pompa air rumah tangga, kualitas daya listrik 


\section{PENDAHULUAN}

Pemenuhan kebutuhan hidup sehari-hari dengan memanfaatkan sinar matahari untuk diubah langsung / konversi langsung menjadi energi listrik dengan menggunakan modul surya menarik untuk diteliti dalam hal penggunaannya, hal-hal apa saja yang harus diperhitungkan agar sistem tetap berjalan secara berkesinambungan dalam penggunaannya. Bahkan perlu adanya pengkajian pada kualitas daya yang ditimbulkan oleh inverter dan peralatan listrik rumah tangga agar tidak merusak peralatan-peralatan listrik yang lainnya. Dengan menggunakan alat ukur yang sesuai maka kita mengukur kualitas daya listrik yang dihasilkan dari sistem modul surya sederhana yang kita buat.

Penelitian dalam pembuatan Analisis Kualitas Daya Listrik Pada Penggunaan Modul Surya Sederhana Untuk Pompa Air Rumah Tangga mengacu dari beberapa referensi yang sebelumnya sudah dilakukan antara lain tentang perancangan dan pengembangan modul surya untuk peralatan rumah tangga sebagai sumber energi baru terbarukan seperti pada [1,2,3,4,5], selain itu berkembang juga penelitian kualitas daya pada sistem kelistrikan yang diakibatkan oleh pemakaian beberapa peralatan listrik seperti pada $[6,7,8,9,10,11]$. Kemudian beberapa penelitian dalam bidang harmonik berupa penyebab, akibat, pengkuran, dan analisisnya juga sudah dilakukan seperti pada $[12,13,14,15,16]$. Roadmap penelitian yang sudah dilakukan pada tahun 2018 dan yang akan dilakukan pada tahun 2019 Dan beberapa teori yang mendukung dalam penelitian ini meliputi teori tentang sel surya dan beberapa karakteristiknya.

\section{METODE PENELITIAN}

\subsection{Sistem Kerja Diagram Sistem Modul Surya Sederhana}

Blok diagram rangkaian memerlukan salah satu bagian yang terpenting dalam perancangan suatu alat, karena blok diagram rangkaian inilah dapat diketahui cara kerja rangkaian keseluruhan. Sehingga keseluruhan blok diagram rangkaian tersebut akan menghasilkan suatu system yang dapat difungsikan atau dapat bekerja sesuai perencangan.

Sistem kerja PLTS di terdiri dari panel surya, solar charge controller, baterai, dan inverter. Adapun skema system PLTS tersebut adalah sebagai berikut:

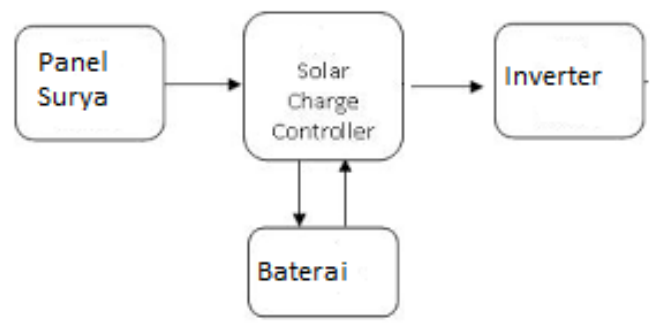

Gambar 1. Blok diagram PLTS menggunakan modul surya

Tujuan dari pembuatan blok diagram pada gambar 1 yaitu :

a. Solar cell yang digunakan pada rancang bangun berfungsi untuk menyerap energi matahari yang kemudian akan dikeuarkan dalam besaran volt

b. Solar charge controller berfungsi untuk mengisi baterai dengan arus konstan hingga mencapai tegangan yang ditentukan.

c. Baterai berfungsi untuk menyimpan muatan dari solar cell.

d. Inverter berfungsi mengubah daya arus DC menjadi daya arus AC. 


\section{KILAT}

Vol. 10, No. 1, April 2021, P-ISSN 2089-1245, E-ISSN 2655-4925

DOI: https://doi.org/10.33322/kilat.v10i1.1037

\subsection{Komponen Sistem Modul Surya}

\subsubsection{Modul Surya}

Panel surya yang digunakan mempunyai rating daya $200 \mathrm{Wp}$. Besar rating berbeda disebabkan karena karakteristik modul surya jenis $\mathrm{P}-\mathrm{N}$ dan juga dipengaruhi oleh jumlah sel terhadap luas dari modul tersebut.

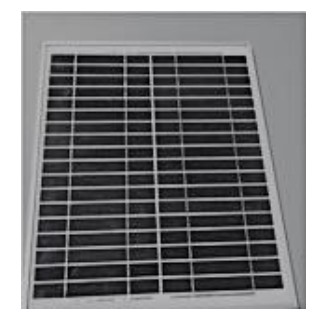

Gambar 2. Modul surya 200 WP

\subsubsection{Solar Charge Controller}

Solar charge controller yang digunakan adalah sebanyak 1 buah dengan Solar Charger Controller 12/24 V MPPT.

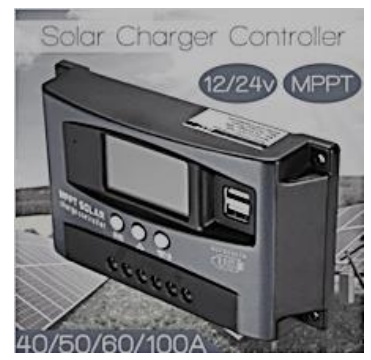

Gambar 3. Solar Charge Controller SC-991

\subsubsection{Baterai}

Baterai bank yang menggunakan 44nergy tegangan 12V. Terdiri dari 1 buah baterai dengan kapasitas 3,5 Ah.

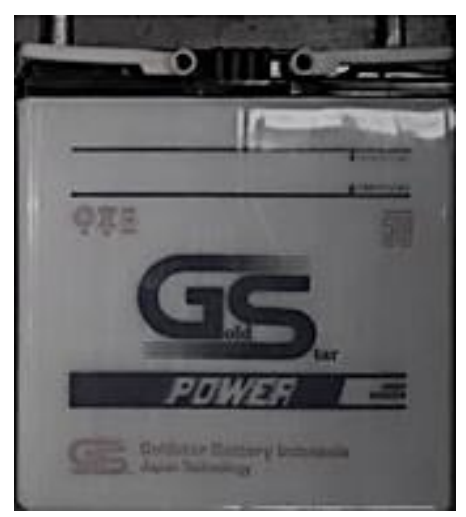

Gambar 4. Baterai

\subsubsection{Inverter}

Inverter merupakan suatu alat yang berfungsi untuk mengubah arus DC menjadi arus AC. Pada PLTS, inverter berfungsi sebagai pengkondisi tenaga listrik (power condition) dan energi yang merubah arus listrik searah (DC) yang dihasilkan oleh solar modul menjadi listrik arus bolak-balik (AC), yang nantinya akan mengontrol kualitas daya listrik yang dikeluarkan untuk dikirim ke beban atau jaringan listrik Terdapat dua macam energy inverter pada PLTS yaitu: 
1. Inverter 1 fasa untuk energi PLTS yang bebannya kecil.

2. Inverter 3 fasa untuk energi PLTS yang besar dan terhubung dengan jaringan PLN. Berdasarkan karakteristik dari performa yang dibutuhkan, inverter untuk energi PLTS berdiri sendiri (stand-alone) dan PLTS grid-connected memiliki karakteristik yang berbeda, yaitu:

1. Pada PLTS stand-alone, inverter harus mampu mensuplai tegangan AC yang konstan pada variasi produksi dari modul surya dan tuntutan beban (load demand) yang dipikul.

2. Pada PLTS grid-connected, inverter dapat menghasilkan kembali tegangan yang sama persis dengan tegangan jaringan pada waktu yang sama, untuk mengoptimalkan dan memaksimalkan keluaran energy yang dihasilkan oleh modul surya.

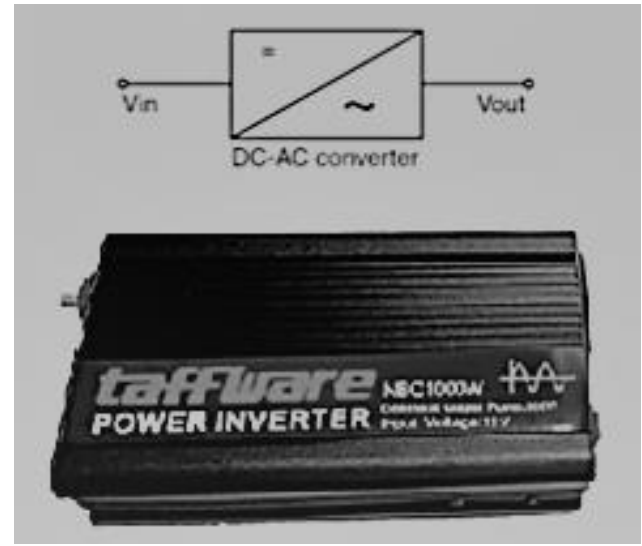

Gambar 5. Inverter

\subsection{Parameter Keadaan Steady-State)}

Keadaan Steady-State merupakan kondisi suatu sistem yang berada pada kondisi mantap (teratur). Parameter yang dipakai untuk menilai mutu listrik keadaan Steady-State adalah variasi tegangan.

Tabel 1. Standar tegangan SPLN 1: 1995

\begin{tabular}{|c|c|}
\hline $\begin{array}{c}\text { Tegangan Nominal } \\
(\mathrm{V})\end{array}$ & $\begin{array}{c}\text { Variasi Tegangan Pelayanan } \\
(\%)\end{array}$ \\
\hline $230 / 400$ & $+5 \% \mathrm{dan}-10 \%$ \\
$400 / 690$ & \\
1000 & \\
\hline
\end{tabular}

\subsection{Distorsi Harmonik}

Total Distorsi Harmonik (THD) merupakan rasio nilai rms dari komponen harmonisa dengan nilai rms dari komponen dasar yang biasanya dinyatakan dalam persen (\%). Nilai THD dijadikan batasan tegangan atau arus harmonik yang masih dapat ditoleransi dalam suatu sistem tenaga listrik. Dengan adanya parameter ini, maka dapat dilihat apakah distorsi yang terjadi dalam kondisi yang masih bisa diterima sistem atau tidak. Nilai ini untuk arus ataupun tegangan dapat dihitung dengan rumus sebagaimana dijelaskan pada [13].

Arus harmonik akan mengakibatkan distorsi bentuk gelombang tegangan sehingga tidak berbentuk sinusoidal murni lagi. Hal ini sangat mengganggu bagi peralatan listrik yang didesain beroperasi pada gelombang tegangan sinusoidal. Akibatnya banyak kerugian yang akan diderita, di antaranya peralatan listrik menjadi lebih cepat panas sehingga dapat terjadi kegagalan isolasi yang berujung pada kerusakan atau makin pendek umur dari peralatan. 


\section{KILAT}

Vol. 10, No. 1, April 2021, P-ISSN 2089-1245, E-ISSN 2655-4925

DOI: https://doi.org/10.33322/kilat.v10i1.1037

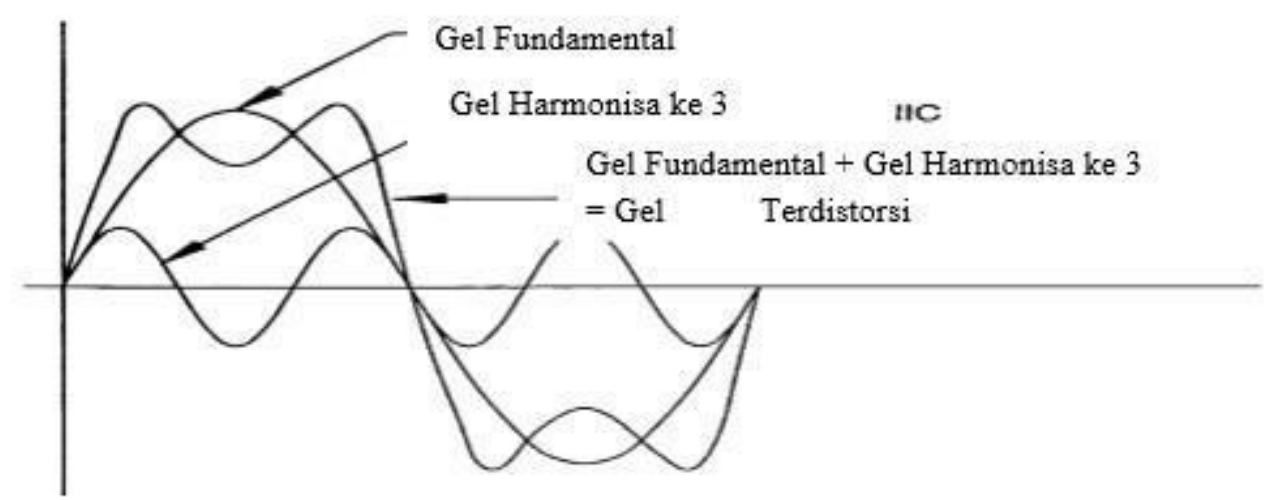

Gambar 6. Gelombang Terdistorsi, fundamental, harmonisa ke 3

\section{a. Distorsi harmonik total/total harmonic distortion (THD)}

Faktor distorsi menggambarkan tingkat gangguan harmonik pada jaringan listrik. Ada beberapa pengukuran yang umum digunakan, salah satu yang paling umum adalah distorsi harmonik total (THD) yang akan digunakan dalam penelitian ini, untuk tegangan ataupun arusnya.

$$
T H D=\frac{\sqrt{\sum_{h>1}^{\infty} M_{h}^{2}}}{M_{1}} \times 100
$$

Dimana :

THD $=$ Total Harmonik Distortion

$\mathrm{Mh}=$ Nilai RMS dari arus atau tegangan dari komponen harmonik ke-h

$\mathrm{M}_{1}=$ Nilai RMS dari arus atau tegangan dari frekuensi dasar.

\section{b. Batas Distorsi Harmonik}

Ada berbagai batas distorsi harmonik di beberapa negara. Kebanyakan Industri menggunakan batas distorsi yang dikeluarkan oleh IEEE std-519-1992.

A. Batas Distorsi Arus

Tabel 2. Batas distorsi arus (120 V sampai $69 \mathrm{kV})$

\begin{tabular}{|c|c|c|c|c|c|c|}
\hline \multicolumn{7}{|c|}{ Distorsi arus harmonik maksimum (Ih \% dari IL) } \\
\hline \multicolumn{7}{|c|}{ Urutan harmonik individual (harmonik ganjil) } \\
\hline $\mathrm{Isc} / \mathrm{IL}$ & $<11$ & $11 \leq \mathrm{h}<17$ & $17 \leq \mathrm{h}<23$ & $23 \leq \mathrm{h}<35$ & $35 \leq \mathrm{h}$ & $\mathrm{THDi}$ \\
\hline$<20$ & 4.0 & 2.0 & 1.5 & 0.6 & 0.3 & 5.0 \\
\hline $20<50$ & 7.0 & 3.5 & 2.5 & 1.0 & 0.5 & 8.0 \\
\hline $50<100$ & 10.0 & 4.5 & 4.0 & 1.5 & 0.7 & 12.0 \\
\hline
\end{tabular}

B. Batas Distorsi Tegangan

Tabel 3. Batas distorsi tegangan

\begin{tabular}{|c|c|c|}
\hline Tegangan Bus pada PCC & Batas harmonik individual (\%) & THDV (\%) \\
\hline $\mathrm{V} \leq 69 \mathrm{KV}$ & 3 & 5 \\
\hline $69 \mathrm{Vn}-161$ & 1.5 & 2.5 \\
\hline $\mathrm{V} \geq 161$ & 1 & 1.5 \\
\hline
\end{tabular}




\section{HASIL DAN PEMBAHASAN}

\subsection{Pelaksanaan Penelitian}

Tangerang adalah sebuah daerah yang terletak di Tangerang Provinsi Banten. PLTS ini hanya sebuah prototipe dengan 2 buah panel $200 \mathrm{Wp}$.

Setelah memperoleh hasil pengukuran dan perhitungan, maka akan diperoleh data-data hasil. Dari data yang diperoleh pada beberapa keadaan, diantaranya:

1. Pengukuran dilakukan menggunakan AVO meter dan alat ukur harmonisa.

2. Pengukuran dan perhitungan konsumsi energi listrik yang diperlukan untuk pompa air dan peralatan listrik rumah tangga.

3. Pengukuran dan perhitungan faktor daya dan harmonisa listrik dari inverter dan peralatan listrik rumah tangga.

\subsection{Cara Pengujian}

Pengujian dan cara pengambilan data pada prototipe ini dengan mengukur tegangan (V), arus (I), daya (P), faktor daya, dan THD (Total Harmonic Distorsion) pada pemakaian peralatan listrik rumah tangga yang dipergunakan dengan menggunakan AVO meter dan alat ukur Harmonisa. Adapun langkah kerja dalam pengujian ini sebagai berikut:

1. Mengukur tegangan, arus, faktor daya dan daya listrik yang dipakai pada pompa air dan peralatan listrik rumah tangga.

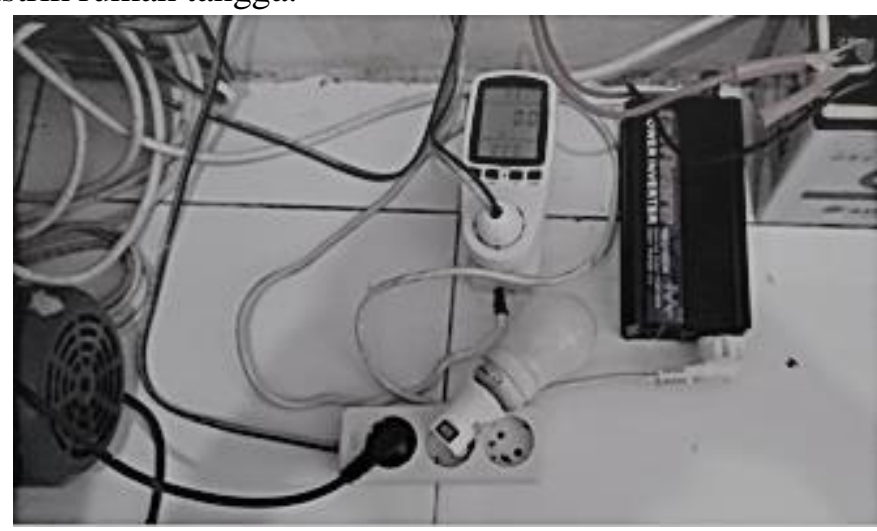

Gambar 7. Pengukuran pemakaian peralatan listrik.

2. Mengukur harmonik tegangan yang ditimbulkan oleh inverter dan peralatan listrik rumah tangga.

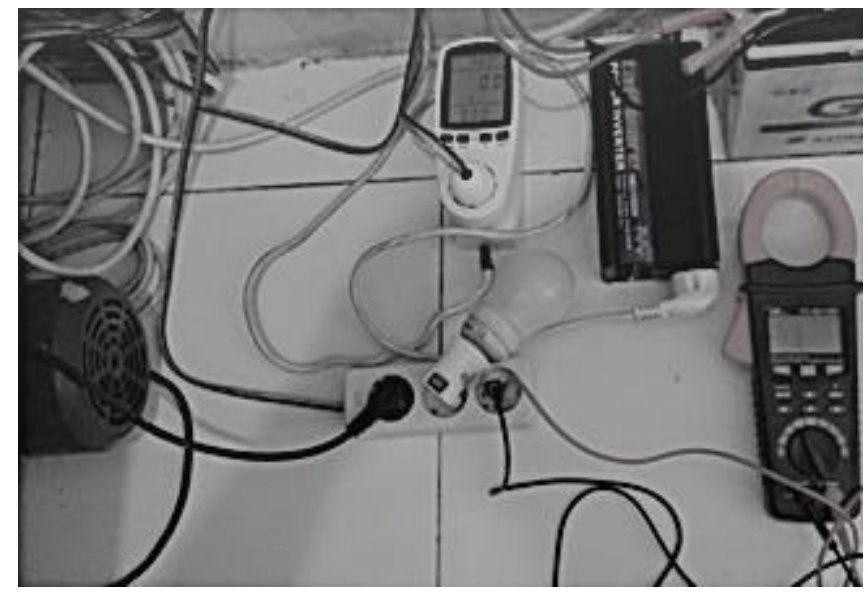

Gambar 8. Pengukuran harmonisa tegangan dengan menggunakan alat ukur 


\section{KILAT}

Vol. 10, No. 1, April 2021, P-ISSN 2089-1245, E-ISSN 2655-4925

DOI: https://doi.org/10.33322/kilat.v10i1.1037

Setelah pengukuran tegangan, arus, daya, faktor daya dan THD maka dibuatlah tabel daya penggunaan peralatan listrik dan tabel faktor daya-harmonik peralatan listrik yang dipergunakan.

\subsection{Hasil Penelitian}

Adapun hasil tersebut sebagaimana tertuang pada tabel dengan dilengkapi dengan grafik dari hasil perolehan tabel yang ada. Untuk mengetahui nilai yang ada dengan menggunakan avo meter.

\subsubsection{Hasil pengukuran tegangan, arus, faktor daya, dan daya listrik pada pemakaian pompa air dan peralatan listrik rumah tangga}

Tabel 4. Data pada pengukuran tegangan, arus, faktor daya dan daya listrik pada pemakaian pompa air dan peralatan listrik rumah tangga.

\begin{tabular}{|c|c|c|c|c|}
\hline Jam & Tegangan (V) & Arus (I) & $\begin{array}{c}\text { Faktor } \\
\text { Daya } \\
(\mathrm{PF})\end{array}$ & Daya $(\mathrm{P})$ \\
\hline $0: 30$ & 221,6 & 0,273 & 0,99 & 61,2 \\
\hline $1: 00$ & 225,2 & 0,273 & 0,99 & 61,8 \\
\hline $1: 30$ & 225,9 & 0,273 & 0,99 & 62,2 \\
\hline $2: 00$ & 222,6 & 0,273 & 0,99 & 60,5 \\
\hline $2: 30$ & 220,6 & 0,273 & 0,99 & 60 \\
\hline $3: 00$ & 222,6 & 0,273 & 0,99 & 60,3 \\
\hline $3: 30$ & 223,4 & 0,273 & 0,99 & 61,2 \\
\hline 4:00 & 221,4 & 0,273 & 0,99 & 60,4 \\
\hline $4: 30$ & 223,4 & 0,273 & 0,99 & 61,2 \\
\hline $5: 00$ & 222,6 & 0,273 & 0,99 & 60,5 \\
\hline $5: 30$ & 225,1 & 0,273 & 0,99 & 61,8 \\
\hline 6:00 & 222,6 & 0,273 & 0,99 & 60,3 \\
\hline $6: 30$ & 223,4 & 0,273 & 0,99 & 61,2 \\
\hline $7: 00$ & 223,6 & 0,273 & 0,99 & 61 \\
\hline $7: 30$ & 225,8 & 0,273 & 0,99 & 62,1 \\
\hline $8: 00$ & 223,5 & 0,273 & 0,99 & 61,1 \\
\hline $8: 30$ & 223,3 & 0,273 & 0,99 & 60,9 \\
\hline $9: 00$ & 223,2 & 0,273 & 0,99 & 61,2 \\
\hline $9: 30$ & 215,5 & 3,631 & 0,95 & 748,3 \\
\hline 10:00 & 222,6 & 0,273 & 0,98 & 60,5 \\
\hline $10: 30$ & 224 & 0,273 & 0,99 & 61,2 \\
\hline 11:00 & 222,6 & 0,273 & 0,98 & 60,3 \\
\hline $11: 30$ & 224,2 & 0,273 & 0,99 & 61,3 \\
\hline 12:00 & 224 & 0,273 & 0,99 & 61,2 \\
\hline $12: 30$ & 224,6 & 0,273 & 0,99 & 61,3 \\
\hline 13:00 & 224,3 & 0,273 & 0,99 & 61,3 \\
\hline $13: 30$ & 223,6 & 0,273 & 0,99 & 61,1 \\
\hline 14:00 & 223,9 & 0,273 & 0,99 & 61,2 \\
\hline
\end{tabular}




\begin{tabular}{|c|c|c|c|c|}
\hline $14: 30$ & 223,9 & 0,273 & 0,99 & 61,2 \\
\hline $15: 00$ & 223,6 & 0,273 & 0,99 & 61,2 \\
\hline $15: 30$ & 223 & 0,273 & 0,98 & 60,8 \\
\hline $16: 00$ & 223,6 & 0,273 & 0,99 & 61,2 \\
\hline $16: 30$ & 224,1 & 0,273 & 0,99 & 61,3 \\
\hline $17: 00$ & 223,6 & 0,273 & 0,99 & 61,2 \\
\hline $17: 30$ & 223,5 & 0,273 & 0,99 & 61 \\
\hline $18: 00$ & 223,7 & 0,273 & 0,99 & 61,1 \\
\hline $18: 30$ & 223,6 & 0,274 & 0,99 & 61,2 \\
\hline $19: 00$ & 225,1 & 0,274 & 0,98 & 61,8 \\
\hline $19: 30$ & 225,8 & 0,275 & 0,99 & 62,1 \\
\hline $20: 00$ & 222,6 & 0,273 & 0,98 & 60,5 \\
\hline $20: 30$ & 219,1 & 3,560 & 0,94 & 740,6 \\
\hline $21: 00$ & 222,6 & 0,273 & 0,98 & 60,5 \\
\hline $21: 30$ & 220,6 & 0,272 & 0,98 & 60 \\
\hline $22: 00$ & 221,4 & 0,272 & 0,99 & 60,4 \\
\hline $22: 30$ & 222,6 & 0,273 & 0,98 & 60,3 \\
\hline 23.00 & 223,4 & 0,273 & 0,98 & 61,2 \\
\hline $23: 30$ & 223,6 & 0,272 & 0,98 & 61 \\
\hline $24: 00$ & 223,5 & 0,273 & 0,98 & 61,2 \\
\hline Rata-rata & 223,167 & 0,411 & 0,986 & 89,508 \\
\hline
\end{tabular}

Perhitungan energi yang dipakai dengan menggunakan daya rata-rata:

Epv $\quad=\mathrm{P}$ x Waktu

$=89,508$ Watt $\times 24$ jam $=2148,2 \mathrm{Wh}=2,1482 \mathrm{kWh}$

Perhitungan energi dengan cara pemisahan pemakaian listrik :

$$
\begin{aligned}
& \mathrm{E}_{\text {Lamp }}=\mathrm{P}_{\text {Lamp }} \mathrm{X} \text { Waktu } \\
& =61,025 \mathrm{Watt} \times 24 \mathrm{jam}=1464,6 \mathrm{Wh}=1,4646 \mathrm{kWh} \\
& \mathrm{E}_{\text {Pompa }}=\left(\text { P }_{\text {Pompa1 }} \mathrm{x} \text { Waktu1 } 20 \text { menit }\right)+(\text { P Pompa2 } \mathrm{x} \text { Waktu2 } 27 \text { menit }) \\
& =(682,8 \times 0,333)+(682,4 \times 0,45)=227,3724+307,08=534,4524 \mathrm{Wh} \\
& \mathrm{E}_{\text {total }}=\mathrm{E}_{\text {Lamp }}+\mathrm{E}_{\text {Pompa }}=1464,6+534,4524=1999,0524 \mathrm{Wh}=1,999 \mathrm{kWh}
\end{aligned}
$$

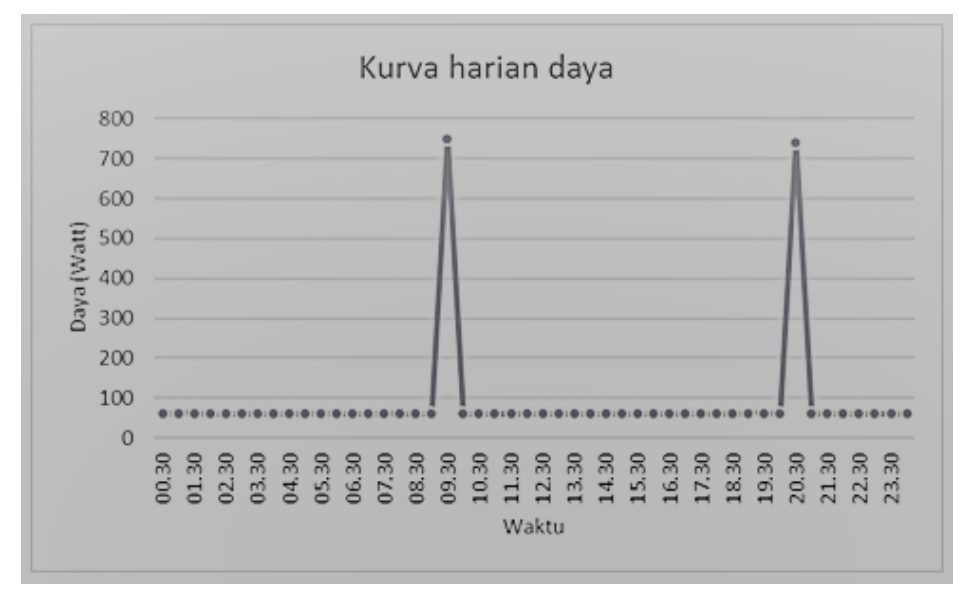

Gambar 9. Grafik Daya penggunaan peralatan listrik dengan waktu 


\section{KILAT}

Vol. 10, No. 1, April 2021, P-ISSN 2089-1245, E-ISSN 2655-4925

DOI: https://doi.org/10.33322/kilat.v10i1.1037

Berdasarkan Gambar 9 terlihat bahwa jam 20.30 adalah yang menggunakan daya yang paling besar. Dimana pada keadaan ini menimbulkan juga lonjakan harmonisa pada sistem kelistrikan. Hasil pengukuran tegangan listrik memberikan kisaran tegangan antara 215,5 Volt $-225,9$ Volt pada beban pompa air dan lampu bohlamp yang menunjukkan bahwa nilai tegangan masih sesuai dengan standar SPLN 1:1995 (+5 \% dan $-10 \%)$.

\subsubsection{Hasil pengukuran faktor daya dan harmonisa tegangan yang ditimbulkan oleh inverter dan peralatan listrik rumah tangga.}

Tabel 5. Data pengukuran harmonisa tegangan yang ditimbulkan oleh inverter dan peralatan listrik rumah

\begin{tabular}{|c|c|c|c|}
\hline \multicolumn{2}{|c|}{ Beban Pompa Air (Motor) } & \multicolumn{2}{|c|}{ Beban Lampu Bohlamp } \\
\hline $\begin{array}{c}\text { Tegangan } \\
\text { Harmonisa }\end{array}$ & (Volt) & $\begin{array}{c}\text { Tegangan } \\
\text { Harmonisa }\end{array}$ & (Volt) \\
\hline 1 & 224,6 & 1 & 226,4 \\
\hline 2 & 1,2 & 2 & 1,5 \\
\hline 3 & 3,5 & 3 & 3 \\
\hline 4 & 1,1 & 4 & 0,4 \\
\hline 5 & 0,9 & 5 & 0,5 \\
\hline 6 & 0,7 & 6 & 0,4 \\
\hline 7 & 0,5 & 7 & 0,5 \\
\hline 8 & 0,5 & 8 & 0,3 \\
\hline 9 & 0,5 & 9 & 0,5 \\
\hline 10 & 0,5 & 10 & 0,3 \\
\hline 11 & 0,3 & 11 & 0,3 \\
\hline 12 & 0,3 & 12 & 0,3 \\
\hline 13 & 0,3 & 13 & 0,3 \\
\hline 14 & 0,3 & 14 & 0,3 \\
\hline 15 & 0,3 & 15 & 0,3 \\
\hline 16 & 0,3 & 16 & 0,3 \\
\hline 17 & 0,3 & 17 & 0 \\
\hline 18 & 0,3 & 18 & 0,3 \\
\hline 19 & 0,3 & 19 & 0 \\
\hline 20 & 0,3 & 20 & 0,3 \\
\hline 21 & 0 & 21 & 0 \\
\hline $2 \mathrm{~s} / \mathrm{d} 21$ & 12,24 & $3 \mathrm{~s} / \mathrm{d} 21$ & 9,8 \\
\hline $1 \mathrm{~s} / \mathrm{d} 21$ & 237 & $1 \mathrm{~s} / \mathrm{d} 21$ & 236,2 \\
\hline THDv & $1,9 \%$ & THDv & $1,6 \%$ \\
\hline
\end{tabular}

Berdasarkan tabel 5 terlihat bahwa dari hasil perhitungan yang didapat pada THD tegangan, THDv pada beban pompa air didapat 1,9\% sedangkan pada lampu bohlamp 1,6 \%. Dalam hal ini kualitas daya listrik yang dihasilkan inverter masih bagus dan tidak berbeda jauh dari hasil pengukuran yang didapat sekitar 1,9\%, jika dibandingkan dengan standar IEEE 519-1992. Meskipun didalam inverter terdapat komponen-komponen non linier yang dapat mengakibatkan terjadinya 
harmonik dari hasil analisa menunjukkan THDv yang terjadi masih bagus dibawah standar yang ditetapkan IEEE 519-1992.

\section{KESIMPULAN DAN SARAN}

Dari hasil analisis kualitas daya listrik Pembangkit Listrik Tenaga Surya (PLTS) Off-grid dengan kapasitas $400 \mathrm{Wp}$ dari sisi keluaran inverter dengan beban pompa air $680 \mathrm{~W}$ dan 1 buah lampu pijar 60 Watt dapat disimpulkan sebagai berikut :

1. Nilai faktor daya yang ditimbulkan sebesar 0,95 sedangkan nilai total harmonik distorsi tegangan (THDv) yaitu pada beban pompa air THDv 1,9\% dan pada beban lampu pijar THDv 1,6\%. Berdasarkan hasil perhitungan pada masing-masing beban bahwa nilai THDv masih diatas batas standar yang ditetapkan IEEE 519-1992 sebesar 5\%.

2. Hasil pengukuran tegangan listrik memberikan kisaran tegangan antar 215,5 Volt $-225,9$ Volt pada beban pompa air dan beban lampu pijar yang menunjukan bahwa nilai tegangan yang terukur masih sesuai batas acuan yang diizinkan SPLN 1:1995 (+5\% dan -10\%).

3. Dari analisa tersebut, kualitas daya listrik yang dihasilkan inverter yang digunakan pada Pembangkit Listrik Tenaga Surya (PLTS) off-grid solar home sederhana $400 \mathrm{Wp}$ masih terbilang bagus.

\section{UCAPAN TERIMAKASIH}

Penulis mengucapkan terima kasih kepada LPPM STT-PLN yang telah memberi dukungan yang membantu pelaksanaan penelitian dan atau penulisan artikel.

\section{DAFTAR PUSTAKA}

[1]. Rumbayan, "Radiasi Matahari di Indonesia". Jakarta. PT.Green Energi Indotama.

[2]. Lynn, Paul A. 2010. “ Electricity from Sunlight : An Introduction to Photovoltaic”. Bristol Wiley.

[3]. Santiari, Dewa Ayu Sri. 2011. "Studi Pemanfaatan PLTS Sebagai catu Daya Tambahan pada Industri Perhotelan di Nusa Lembongan Bali”. Denpasar. Teknik Elektro Universitas Udayana.

[4]. Hajar, Ismu. 2015. "Studi Perencanaan Penambahan Daya Pada Pembangkit Listrik Tenaga Surya, Pulau Salemo”. Jakarta. Teknik Elektro STT-PLN.

[5]. Kementrian ESDM. 2016. "Rencana Usaha Penyediaan Tenaga Listrik PT. Perusahaan Listrik Negara (Persero) tahun 2016-2025". Jakarta.

[6]. K. E. Wilson And A. M. Henry. April 1992. "Expert System Target Power Quality Issues". IEEE.

[7]. Kennedy Barry W. 2000. "Power Quality Primer". McGraw-Hill.

[8]. S. John And Collinson Alan. 2001. “Power Quality”. IEEE Power Engineering Journal.

[9]. B. Amanga, F. Francisco, O. Javier, And I.L. Jose. Oktober 2007. “New Power Quality Solutions Esecially Designed For Industrial Applications". Barcelona. International Conference Electrical Power Quality And Utilization.

[10]. Irawati Rina 2013, “ Micro-Grid PLTS, Batere dan PLN Untuk Menjaga Kualitas Daya di Industri”.

[11]. Lestari Ayu. 2016. “ Analisis Kinerja PLTS Bunaken 335 kWp Di Manado”. Jakarta. Skripsi Sekolah Tinggi Teknik - PLN.

[12]. Dugan Roger C, Mark F McGranaghan, and H Wayne Beaty. 1996. "Electrical Power Systems". McGraw-Hill. 


\section{KILAT}

Vol. 10, No. 1, April 2021, P-ISSN 2089-1245, E-ISSN 2655-4925

DOI: https://doi.org/10.33322/kilat.v10i1.1037

[13]. Arrilangga J., Bradley D.A, Bodger P.S. 1985. “ Power System Harmonic”. New York. John Willey \& Sons.

[14]. Subjak, Joseph S. \& McQuilkin, John S. 1990." Harmonic-Causes, Effect, Measurements, And Analysis : An Update". Journal of IEEE Transactions In Industry Applications, 1024-1041.

[15]. IEEE Std. 519-1992. 1994. "IEEE Guide for Harmonic Control and Reactive Compensation of Static Power Converter". Internet.

[16]. IEEE Std.519 ${ }^{\mathrm{TM}}$. 2014. " Recommended Practice And Requirements For Harmonic Control In Electric Power Systems". 